\title{
Consumo e Desenvolvimento Sustentável: um olhar sobre o comportamento de estudantes universitários em relação aos hábitos de consumo e de descarte de aparelho celulares
}

\author{
Josimari de Brito Morigi ${ }^{1}$ \\ Marcos Junio Ferreira de Jesus ${ }^{2}$
}

\begin{abstract}
RESUMO
O presente estudo almeja realizar uma análise do comportamento de estudantes universitários em relação aos hábitos de consumo e de descarte de aparelhos celulares em desuso, e tem como foco principal a preocupação com os aparelhos celulares que não recebem um descarte ambientalmente correto. Realizou-se o levantamento bibliográfico e a aplicação de questionários estruturados junto aos estudantes do curso de Administração de uma Instituição de Ensino Superior, localizada na Mesorregião Centro Ocidental - Paranaense. Os resultados evidenciam que o público investigado, em sua maioria, busca trocar de aparelho celular com certa frequência, especialmente para obter benefícios atrelados à evolução da tecnologia: aparelhos mais modernos, rápidos e eficientes, com uma funcionalidade melhor em relação ao espaço da memória e o uso de aplicativos, e também pela curta vida útil dos aparelhos. Também se constatou que o nível de conhecimento da maioria dos estudantes em relação ao descarte ecologicamente correto é satisfatório, porém, a grande maioria afirmou que obtém na internet as informações sobre o descarte de celulares. Ademais, vários estudantes atestaram que possuem um ou mais aparelhos celulares em desuso guardados em suas residências, demonstrando, portanto, a necessidade de ações por parte das empresas fabricantes e comercializadoras de tais produtos e do poder público no sentido de informar os riscos e os prejuízos que o descarte incorreto do lixo eletrônico pode acarretar e também indicar e disponibilizar os locais adequados para se fazer o descarte.
\end{abstract}

Palavras-chave: Estudantes Universitários; Resíduos Eletroeletrônicos; Aparelhos celulares; Consumo e Desenvolvimento Sustentável; Destinação Ambientalmente Correta.

\section{Consumption and Sustainable Development: a look at the behavior of university students in relation to the habits of consumption and disposal of cellular devices}

\begin{abstract}
The present study aims to carry out an analysis of the behavior of university students in relation to consumption habits and disposal of disused cell phones, and its main focus is the concern with cell phones that do not receive an environmentally correct disposal. A bibliographic survey and structured questionnaires were carried out with students of the Administration course of a Higher Education Institution, located in the Mesorregião Centro Ocidental - Paranaense. The results show that the investigated public, for the most part, seeks to change cell phones with a certain frequency, especially to obtain benefits linked to the evolution of technology: more modern, fast and efficient devices, with a better functionality in relation to the memory space and the use of applications, and also for the short life of the devices. It was also found that the level of knowledge of most students in relation to ecologically correct disposal is satisfactory, however, the vast majority stated that they obtain information on the disposal of cell phones on the internet. In addition, several students attested that they have one or more disused cell phones stored in their homes, demonstrating, therefore, the need for actions by the companies that manufacture and sell these products and the government in order to inform the risks and losses that the incorrect disposal of electronic waste can cause and also indicate and make available the appropriate places to do the disposal.
\end{abstract}

Keywords: University Students; Electrical and Electronic Waste; Cellular Devices; Consumption and Sustainable Development; Environmentally Correct Destination.

\footnotetext{
${ }^{1}$ Mestre em Administração pela Universidade Estadual de Maringá. E-mail: josimorigi@ gmail.com

2 Doutor em Administração Pública e Governo pela Fundação Getúlio Vargas -FGV/EAESP. E-mail: marcos_junio@hotmail.com
} 


\section{INTRODUÇÃO}

Um estudo realizado por diversas agências da ONU (Organização das Nações Unidas), direcionado para a gestão do lixo eletrônico, abrangeu diversos países da América do Sul como a Argentina, Bolívia, Brasil, Chile, Colômbia, Equador, Paraguai, Uruguai e Venezuela e a partir deste estudo foi elaborado um documento, o qual foi intitulado de Gestão Sustentável de Resíduos de Equipamentos Elétricos e Eletrônicos na América Latina. Os dados deste estudo demonstram que o Brasil está em segundo lugar na produção de resíduos de aparelhos econômicos e eletrônicos, estando apenas atrás dos Estados Unidos. Além do mais, no ano de 2014, o Brasil produziu 1,4 milhão de toneladas de lixo eletrônico, o que representa 3,33\% da produção mundial (RELATÓRIO DA ONU - NAÇÕES UNIDAS NO BRASIL, 2015).

Conforme os dados da $30^{\mathrm{a}}$ Pesquisa Anual de Administração e Uso de Tecnologia da Informação nas Empresas, realizada pela Fundação Getúlio Vargas de São Paulo (FGV-SP), divulgados em abril de 2019, o Brasil superou a marca de um smartphone por habitante e no ano anterior contava com 230 milhões de celulares inteligentes ativos. Ademais, a referida pesquisa também estimou que em 2019, o país teria 420 milhões de aparelhos digitais ativos. A pesquisa também evidencia que há 180 milhões de computadores, notebooks e tablets em uso no Brasil. Salienta-se que houve um aumento de 10 milhões no número de smartphones ativos em relação a 2018. Esses dados denotam que o brasileiro tem procurado adquirir aparelhos mais sofisticados, e tal fator tem sido impulsionado pelo barateamento de alguns modelos de smartphones de entrada.

Em contraste a esse crescimento do mercado de eletrônicos, sobretudo, de telefones celulares, emergem questões relacionadas ao uso e ao descarte desses produtos ao final de seu ciclo de vida. Haja vista que, os aparelhos eletrônicos possuem componentes em sua composição que podem representar sérios risco à saúde humana e ao meio ambiente. Apesar disso, somente alguns produtos possuem regulamentação da gestão de seus resíduos, o que inclui a logística reversa e a reciclagem.

O presente estudo almeja realizar uma análise do comportamento de estudantes universitários em relação aos hábitos de consumo e de descarte de aparelhos celulares em desuso, e tem como foco principal a preocupação com os aparelhos celulares que não recebem um descarte ambientalmente correto. Para tanto, se fez necessário observar os seguintes pontos: analisar os problemas encontrados no processo de descarte de aparelhos celulares e 
discutir a importância da conscientização e do acesso a informação por parte dos consumidores sobre a destinação adequada no pós-consumo.

\section{PROCEDIMENTOS METODOLÓGICOS}

A técnica utilizada na pesquisa para a coleta de dados foi a aplicação de questionários estruturados. Trabalhou-se com a amostra por conveniência, pois foi selecionada uma amostra de população mais prontamente disponível para responder ao questionário de pesquisa. $\mathrm{O}$ público investigado foram os estudantes do curso de Administração de uma Instituição de Ensino Superior, localizada na Mesorregião Centro Ocidental - Paranaense, buscando levantar primeiramente informações atreladas ao seu perfil: faixa etária, sexo, renda familiar mensal e município de residência, e em seguida direcionando a investigação para questões ligadas ao hábito de consumo e de descarte de aparelhos celulares.

A presente pesquisa se configura como um estudo de caso, e no tocante aos objetivos, pode ser classificada como exploratória e descritiva. Exploratória, visto que o tema investigado é pouco explorado e a presente pesquisa busca proporcionar uma visão geral quanto ao problema. E descritiva, uma vez que o foco está em identificar as percepções quanto ao descarte de aparelhos celulares, além de levantar opiniões e atitudes da população investigada acerca dessa questão de pesquisa (GIL, 2009).

\section{REFERENCIAL TEÓRICO}

\subsection{Consumo e Desenvolvimento Sustentável}

Com a publicação do Relatório Brundtland no ano de 1987, teve-se a primeira menção ao conceito de desenvolvimento sustentável, o qual defende a utilização racional dos recursos naturais na promoção da satisfação das necessidades da atual geração, de modo a não comprometer a capacidade das gerações futuras em prover suas próprias necessidades.

Nesse contexto, vale mencionar que a definição de desenvolvimento sustentável contemplada no Relatório Brundtland reconhece a nossa dependência enquanto seres humanos, com relação ao meio ambiente, sobretudo no que tange ao consumo de recursos para suprir as nossas necessidades e promover o nosso próprio bem-estar em um sentido muito mais amplo do que simplesmente a exploração de recursos (HOPWOOD et al, 2005). 
Contribuindo com o exposto, cabe frisar que conforme descreve Sodré (1996), o ato de consumir por si só, acaba se opondo a ideia de preservar, portanto, é necessário repensar esta relação. No entanto, a ideia ingênua de preservar pode gerar o risco de esquecer a necessidade do homem de consumir. Assim sendo, o referido autor enaltece que:

Repensar esta sociedade de uma forma realística é absolutamente imprescindível. Não se trata de opor preservação ao consumo, mas de buscar uma saída que pode ser denominada consumo sustentável (SODRÉ, 1996, p. 153).

Ainda no tocante ao desenvolvimento sustentável, salienta-se que para Silva (2012), este pode ser entendido como:

O padrão de consumo resultante da inter-relação de atores sociais, numa perspectiva de interação política, direcionado ao alcance do desenvolvimento sustentável, pressupondo a existência de uma consciência individual (ao considerar o indivíduo como cidadão), de um alinhamento organizacional direcionado aos aspectos socioambientais, por uma atuação governamental ativa, bem como de outros atores pertencentes ao contexto social, por meio da coordenação das práticas e relações existentes na dinâmica do consumo sustentável (SILVA, 2012, p. 255).

De maneira geral, o consumo sustentável corresponde ao modo como a sociedade deveria se comportar em relação ao consumo e a disponibilidade de recursos existentes com o intento de promover um equilíbrio maior para as gerações vindouras. Cortez e Ortigoza (2007) enaltecem a dimensão individual do consumo sustentável, ao explanar que:

Será preciso, igualmente, uma mudança nas atitudes sociais e culturais, de modo que a liberdade pessoal de desfrutar de benefícios materiais aqui e agora seja contrabalançada por um sentimento de responsabilidade compartilhado, a fim de promover o bem-estar de toda a humanidade, incluindo o das gerações futuras (CORTEZ; ORTIGOZA, 2007, p.12).

Conforme destaca Ortigoza (2003) a essência do consumo sustentável está na criação de uma consciência ecologicamente seletiva nos consumidores, de modo a permitir que seja inserido dentro do cotidiano, novos hábitos de consumo, que sejam mais responsáveis e que promovam um menor volume de desperdício. A mesma autora ainda discorre a respeito da adoção dos 3R's da sustentabilidade para evidenciar que é preciso desenvolver uma educação voltada para a redução, haja vista que nem tudo aquilo que consumimos é de fato uma necessidade; para a reutilização, uma vez que muitos dos produtos que consumimos podem ser destinados para novos usos; e por fim, para a reciclagem, já que existe a possibilidade de introduzir novamente ao sistema produtivo, determinados produtos já utilizados, transformando-os em novos produtos. 
Ortigoza (2003) também enfatiza que o consumo sustentável oferece possibilidades de minimização dos impactos decorrentes de resíduos sólidos no espaço citadino, pois não se pode apenas trabalhar com os resultados, isto é, o lixo gerado, também é preciso considerar a criação de mecanismos que promovam a diminuição desta geração. Assim sendo, são necessárias mudanças comportamentais nas relações de consumo.

Nesse ensejo, Pujadas et al. (2009) discorrem que é possível compreender o consumo sustentável a partir de três abordagens: ecológica, econômica e social. Sendo que a abordagem ecológica é marcada pela necessidade ecológica de se realizar mudanças dos atuais padrões de consumo. Ao passo que a abordagem econômica, considera o consumo como o principal fator que estimula o crescimento do mundo e reflete sobre a importância de se encontrar um desenvolvimento econômico que possibilite o suprimento das necessidades humanas, mas que ao mesmo tempo também permita a preservação do entorno natural e assegure uma distribuição equitativa dos recursos mundiais. Já a abordagem social, dedica-se a necessidade de mudança dos hábitos de consumo e dos meios de relação social que são determinados por uma série de critérios e fatores, sendo que estes podem ser resultantes tanto de interesse pessoal, como de motivos sociais.

Nessa conjuntura, vale mencionar a importância do consumo socialmente responsável, que no entendimento de Antil (1984), engloba o comportamento e a tomada de decisão por parte do consumidor em relação a questões ambientais, que são determinadas não somente pelo desejo deste em satisfazer exclusivamente suas necessidades particulares, mas que também acabam por considerar as consequências adversas resultantes de seus efeitos para o meio ambiente.

Acrescenta-se ainda que, conforme pontua Mohr, Webb e Harris (2001) o consumidor socialmente responsável é aquele que realiza a aquisição, o uso e a disposição de produtos, baseados em comportamentos que fomentam um desejo de mitigar os efeitos prejudiciais destes e em contrapartida, possa também maximizar o impacto benéfico para a sociedade a longo prazo. Ressalta-se ainda que os referidos autores ainda defendem que um consumidor socialmente responsável é aquele que não apenas simplesmente procura evitar o consumo de produtos de empresas que prejudicam a sociedade, mas também aquele consumidor que procura se empenhar de forma mais ativa na busca por produtos que sejam fabricados por empresas que de fato contribuem para o bem-estar da sociedade. Diante disto, observa-se que este conceito acaba remetendo para a existência de uma dimensão ativista na construção da responsabilidade social, na medida em que enaltece que o consumidor precisa utilizar o seu 
poder de compra seja para punir como também para premiar produtos e empresas em conformidade com a sua responsabilidade social corporativa.

Conforme pontua Maduro-Abreu (2010), a origem do consumo sustentável nos trouxe uma perspectiva mais abrangente para se pensar o consumo. Segundo o referido autor, passase a não focalizar somente na relação entre o consumo e a utilização de recursos naturais nos processos produtivos, bem como os seus impactos no meio ambiente, e inicia-se a obtenção de uma visão que esteja voltada também para os impactos sociais.

Nesse contexto, vale destacar que existe, portanto, um sentido preventivo no significado de consumo sustentável, de modo a defender que é necessário que o consumo seja garantido para as gerações atuais, mas que seus padrões devem ser alterados com a pretensão de minimizar os impactos ambientais resultantes do descarte inadequado e do uso demasiado dos recursos naturais. Sendo que diversas iniciativas foram adotadas nas últimas décadas a fim de se promover o desenvolvimento sustentável em âmbito global. Dentre elas destacam-se as conferências e os acordos firmados, direcionados para várias questões que têm afligido a humanidade, tais como a Eco-92 realizada em 1992, no Rio de Janeiro que teve como enfoque a questão ambiental, a Conferência sobre direitos humanos, realizada em 1993, em Viena, a Conferência sobre questões populacionais, realizada no Cairo, em 1994, a Conferência sobre as mulheres, realizada em Beijing, em 1995, as Conferências das Nações Unidas sobre Mudanças Climáticas, conhecidas como Conferências das Partes (COP - Conference of the Parties) e que vem acontecendo desde 1995, e que em 2019 teve a sua $25^{\text {a }}$ edição. Também não se pode esquecer do Fórum Mundial de Educação, realizado em Dakar, em 2000, dentre outros.

Nesse ensejo, destaca-se que os Objetivos de Desenvolvimento Sustentável (ODS), definidos no ano de 2015 a partir da realização da 70ª Assembleia Geral das Nações Unidas, representam a continuação de práticas empreendidas em nível global, sobretudo a partir da década de 1990, marcadas pela realização de ciclos de conferências e acordos mundiais, e pela aprovação dos Objetivos de Desenvolvimento do Milênio (ODM), que vigoraram entre os anos 2000 e 2015, que almejavam avançar em uma agenda comum para o desenvolvimento (AÇÃO EDUCATIVA, ASSESSORIA PESQUISA E INFORMAÇÃO, 2017).

Acrescenta-se ainda que o processo de construção dos novos Objetivos de Desenvolvimento Sustentável, também chamados de Pós-2015, se deu a partir de diversas reuniões realizadas com representantes de Estado e das Nações Unidas, e que contaram também com a participação de organizações da sociedade civil e permitiram a realização de 
consultas abertas online, possibilitando que qualquer cidadão interessado pudesse encaminhar suas contribuições ao rascunho da Agenda. Destarte, o processo de definição dos ODS foi considerado mais democrático e abrangente do que aquele realizado para a definição dos antigos ODM (AÇÃO EDUCATIVA, ASSESSORIA PESQUISA E INFORMAÇÃO, 2017).

Salienta-se que os ODS são compostos por 17 objetivos e possuem um total de 169 metas, as quais foram desenvolvidas a partir de cinco elementos estruturantes, conhecidos como áreas de importância crítica para o planeta e para a humanidade, e que foram denominados pela ONU - Organização das Nações Unidas como os 5 Ps: Paz, Prosperidade, Planeta, Pessoas e Parcerias. No Quadro 1 estão expostos os ODS.

Quadro 1 - 17 ODS definidos no ano de 2015 a partir da realização da 70ª Assembleia Geral das Nações Unidas

Objetivo 1 - Acabar com a pobreza em todas as suas formas, em todos os lugares.

Objetivo 2 - Acabar com a fome, alcançar a segurança alimentar e a melhoria da nutrição e promover a agricultura sustentável.

Objetivo 3 - Assegurar uma vida saudável e promover o bem-estar para todos, em todas as idades.

Objetivo 4 - Assegurar a educação inclusiva e equitativa de qualidade, e promover oportunidades de aprendizagem ao longo da vida para todos.

Objetivo 5 - Alcançar a igualdade de gênero e empoderar todas as mulheres e meninas.

Objetivo 6 - Assegurar a disponibilidade e gestão sustentável da água e o saneamento para todos.

Objetivo 7 - Assegurar a todos o acesso confiável, sustentável, moderno e a preço acessível à energia.

Objetivo 8 - Promover o crescimento econômico sustentado, inclusivo e sustentável, emprego pleno e produtivo e trabalho decente para todos.

Objetivo 9 - Construir infraestruturas resilientes, promover a industrialização inclusiva e sustentável e fomentar a inovação.

Objetivo 10 - Reduzir a desigualdade dentro dos países e entre eles.

Objetivo 11 - Tornar as cidades e os assentamentos humanos inclusivos, seguros, resilientes e sustentáveis.

Objetivo 12 - Assegurar padrões de produção e de consumo sustentáveis.

Objetivo 13 - Tomar medidas urgentes para combater a mudança do clima e os seus impactos.

Objetivo 14 - Conservar e usar sustentavelmente os oceanos, os mares e os recursos marinhos para o desenvolvimento sustentável.

Objetivo 15 - Proteger, recuperar e promover o uso sustentável dos ecossistemas terrestres, gerir de forma sustentável as florestas, combater a desertificação, deter e reverter a degradação da terra e deter a perda de biodiversidade.

Objetivo 16 - Promover sociedades pacíficas e inclusivas para o desenvolvimento sustentável, proporcionar o acesso à Justiça para todos e construir instituições eficazes, responsáveis e inclusivas em todos os níveis.

Objetivo 17 - Fortalecer os meios de implementação e revitalizar a parceria global para o desenvolvimento sustentável.

Fonte: Ação Educativa, Assessoria Pesquisa e Informação, 2017.

As discussões arroladas neste artigo estão alinhadas especialmente com o Objetivo 12, o qual defende a necessidade de se assegurar padrões de produção e de consumo sustentáveis.

\subsection{Resíduos de Equipamentos Elétricos e Eletrônicos (REEE) e Política Nacional de Resíduos Sólidos - Lei n. 12.305/2010}


Carvalho e Xavier (2014, p.2) enfatizam que os resíduos de equipamentos eletrônicos podem ser definidos como "aqueles produtos parte ou componentes de Equipamentos Elétricos e Eletrônicos - EEE no pós-consumo". Lembrando que o processo referente à destinação ambientalmente correta dos REEE (Resíduos de Equipamentos Elétricos e Eletrônicos) precisa respeitar alguns critérios para ser desenvolvido de modo apropriado, dentre eles, pode-se citar o uso de tecnologias adequadas no tratamento dos resíduos para a geração de matéria prima, bem como o interesse econômico em reintegrá-la na linha de produção de novos produtos e equipamentos e, também, o interesse dos próprios consumidores em dar a destinação ideal de tais resíduos no pós-consumo, para que esses possam ser reintegrados ao ciclo produtivo.

Pelo fato de os REEE serem mais complexos que o lixo comum, acabam demandando um processo de coleta e de reciclagem mais específico e mais complexo, e em muitos casos, esses são ineficientes e acabam causando a destinação inadequada dos resíduos. Nesse contexto, Afonso (2014) discorre que é cada vez mais notória a presença de equipamentos eletroeletrônicos nos lixões, colocando em risco a qualidade do solo, do lençol freático e do ar, visto que possuem diversos elementos químicos, incluindo alguns muito tóxicos. "Esses elementos quando descartados de maneira incorreta no ambiente ficam sujeitos à ação de fatores climáticos (calor, frio, chuva, vento) que levam à liberação de compostos tóxicos nas águas naturais, na atmosfera e no solo" (AFONSO, 2014, p. 37).

Outra ação bastante comum, mas também muito condenável é a realização da queima de EE (Equipamentos Eletroeletrônicos), uma vez que a incineração dos mesmos acaba liberando na atmosfera alguns metais tóxicos, tais como cádmio, chumbo, mercúrio, etc. Todavia, vale enaltecer que além de os EE apresentarem elementos tóxicos, também possuem metais valiosos tais como ouro, a prata, o cobre, etc, os quais possuem alto valor de mercado (MACHADO, 2015).

Vale frisar que, o consumidor final pode exercer uma forte influência quando escolhe no ato da compra, produtos que foram fabricados por empresas que aplicam medidas sustentáveis em seus processos produtivos. Além disso, o consumidor também precisa se conscientizar e passar a adotar práticas de reutilização dos EE, seja por meio de ações como reparos, recondicionamentos e remanufaturas, ou seja, processos que permitem a ampliação da vida útil do produto e desse modo, ele poderá ser aproveitado ao máximo, e ser encaminhado para a disposição final somente quando não houver mais outra forma de reusálo (CARVALHO; XAVIER, 2014). 
A Lei 12.305/2010 institui a Política Nacional de Resíduos Sólidos (PNRS), a qual, fomenta a prática de hábitos de consumo sustentável, bem como estabelece mecanismos que promovem o incentivo à reciclagem e à reutilização dos resíduos sólidos, assim como a destinação ambientalmente adequada dos dejetos.

Vale enfatizar que a Lei 12.305/2010, em seu art. 33, determina que os fabricantes, os importadores, os distribuidores e os comerciantes de (1) agrotóxicos, seus resíduos e embalagens, bem como outros produtos cuja embalagem, após o uso, se configura como resíduo perigoso; (2) pilhas e baterias; (3) pneus; (4) óleos lubrificantes, seus resíduos e embalagens; (5) lâmpadas fluorescentes, de vapor de sódio e mercúrio e de luz mista; e (6) produtos eletroeletrônicos e seus componentes, a estruturar e implementar sistemas de logística reversa, que permitam o retorno dos produtos após o uso pelo consumidor, de maneira independente do serviço público de limpeza urbana e de manejo dos resíduos sólidos (BRASIL, 2010). Contudo, vale ressaltar que em decorrência de alguns entraves que tornam difícil o entendimento entre os vários atores envolvidos no processo (poder público versus setor privado), ainda não se tem um Acordo Setorial firmado para os eletroeletrônicos.

\subsection{Logística Reversa}

Conforme as informações do Revlog (2009), o fluxo do processo de logística tradicional é caracterizado pela produção do produto, sua estocagem, sua expedição, distribuição e seu consumo, ao passo que o fluxo do processo da logística reversa está relacionado ao retorno de produtos e de embalagens no pós-consumo ao processo produtivo, sendo, portanto, utilizados como matérias primas secundárias. Lembrando que algumas dessas atividades, são de certa forma, bastante similares àquelas que ocorrem no caso de retorno interno de produtos que apresentam algum defeito de fabricação. Portanto, a logística reversa, envolve as atividades relacionadas a coleta, desmonte e processamento de produtos usados ou partes de produtos, proporcionando uma recuperação do mesmo, do ponto de vista ambiental.

Shibao et al. (2010) destacam que as principais atividades da logística reversa são: coleta do material, reprocessamento e distribuição. Além disso, a logística reversa pode ter suas atividades divididas em cinco funções básicas, as quais são:

a) Planejamento, implantação e controle do fluxo de materiais e do fluxo de informações do ponto de consumo ao ponto de origem; b) Movimentação de produtos na cadeia produtiva, na direção do consumidor para o produtor; c) Busca de uma melhor utilização de recursos, seja reduzindo o consumo de energia, seja diminuindo a quantidade de materiais empregada, seja reaproveitando, reutilizando 
ou reciclando resíduos; d) Recuperação de valor e, e) Segurança na destinação após utilização (SHIBAO, MOORI, DOS SANTOS, 2010, p.4.).

Contribuindo com o exposto, vale mencionar que a Política Nacional de Resíduos Sólidos (PNRS, Lei $n^{\circ}$. 12.305/2010) define a logística reversa como um instrumento de desenvolvimento econômico e social caracterizado por um conjunto de ações, procedimentos e meios que almejam a viabilização da coleta e a restituição dos resíduos sólidos ao setor empresarial, permitindo seu reaproveitamento, em seu ciclo ou em outros ciclos produtivos, ou obter outra destinação final que seja ambientalmente adequada.

A Figura 1 ilustra o processo de logística reversa desde quando o material começa a ser fabricado até a sua chegada ao consumidor. Sendo que no momento em que o material deixa de ser útil, poderá ser realizado o desmanche dele para que o mesmo possa ser utilizado como matérias primas-secundárias e produzir novos materiais.

Figura 1 - Esquema da logística reversa

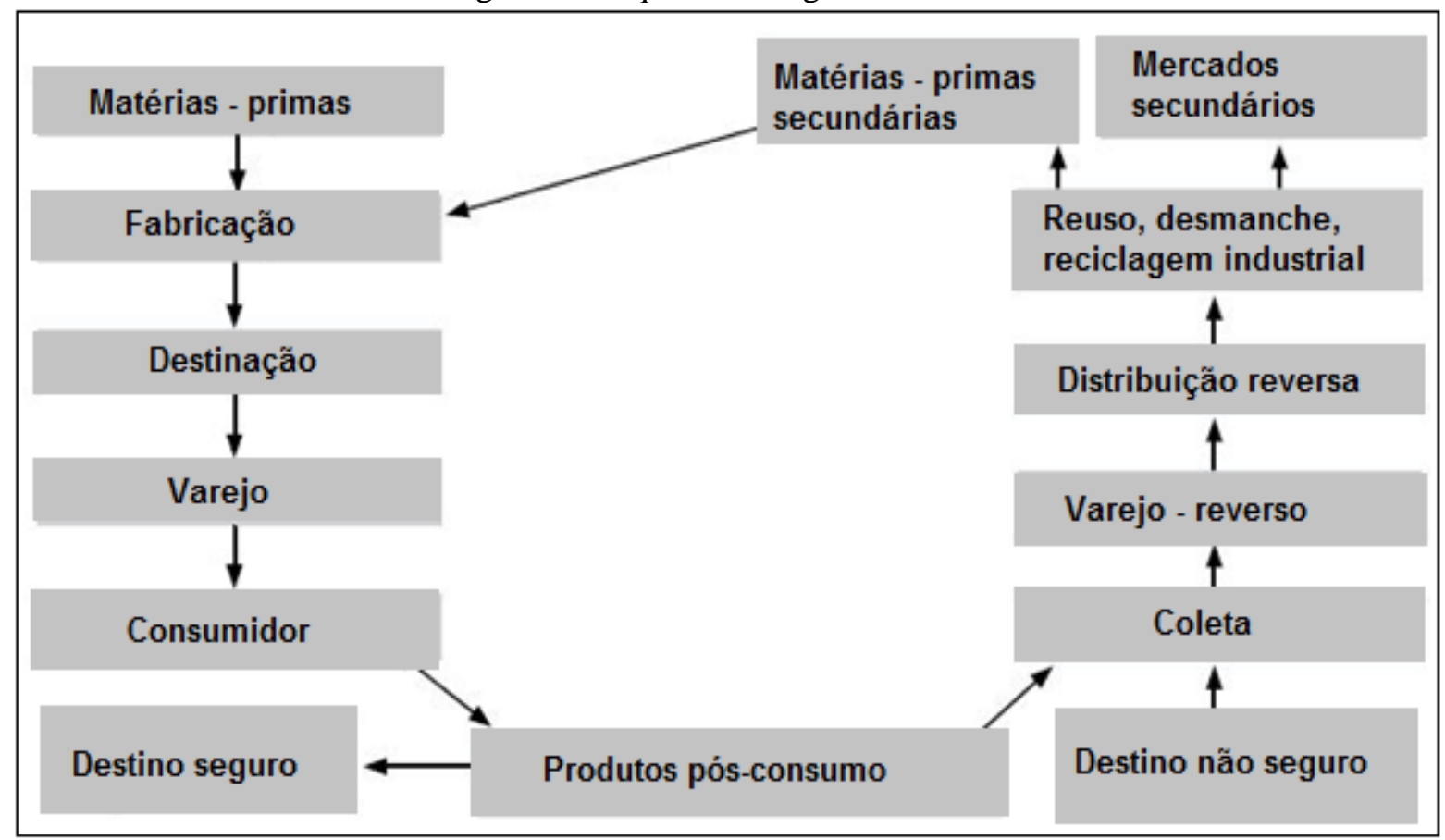

Fonte: Mueller (2012, apud DEMAJOROVIC, 2012).

No Brasil, observa-se que a grande maioria dos estudos voltados para o descarte de produtos eletrônicos, destacam a falta de conscientização dos consumidores, a dificuldade de acesso a coletores específicos, o desconhecimento em relação as técnicas adequadas para se fazer o descarte e até mesmo o desconhecimento sobre os problemas ocasionados pelo descarte incorreto deste tipo de resíduos. 
No estudo de Giaretta et al. (2010), os resultados demonstram que as pessoas até possuem certo nível de consciência de que o descarte inadequado pode comprometer o meio ambiente, no entanto, lhes falta informação sobre como proceder para realizar o descarte correto e onde encontrar os locais adequados para a sua realização.

Acrescenta-se ainda que para a logística reversa se tornar uma realidade tangível, temse a necessidade de empenho de todos os atores envolvidos no processo, haja vista que essa se mostrará pouco efetiva se houver ações isoladas. Portanto, se os elos da cadeia não forem devidamente unidos, o ciclo ficará prejudicado, visto que todas as peças são imprescindíveis para o alcance dos objetivos basilares desta proposta.

\section{RESULTADOS E DISCUSSÕES}

A amostra totalizou 132 respondentes com faixa etária entre 19 e 45 anos, sendo $53,03 \%$ do sexo masculino e 46,97\% do sexo feminino, conforme evidencia a Figura 2. Lembrando que, os respondentes são acadêmicos do Curso de Administração de uma Instituição de Ensino Superior, localizada na Mesorregião Centro Ocidental Paranaense. Lembrando que o referido curso possui atualmente um quadro de 250 alunos ativos.

Figura 2 - Gênero dos respondentes

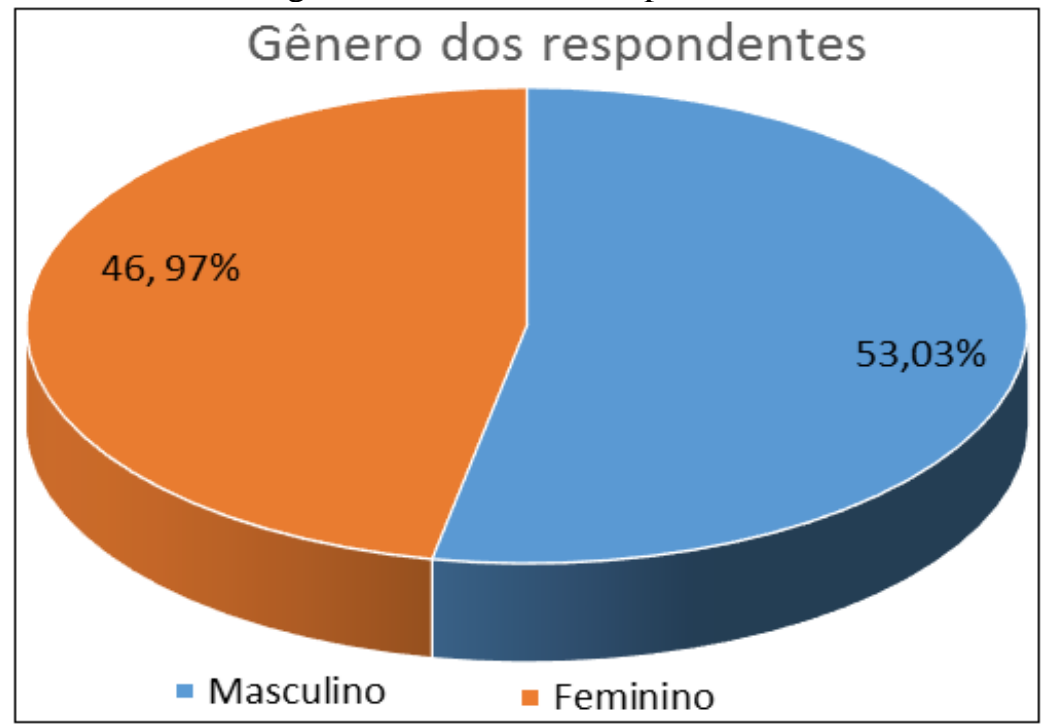

Fonte: Dados da Pesquisa, 2019.

Na amostra, constatou-se a predominância da faixa etária de 19 a 21 anos, sendo que nesta faixa etária há um predomínio de mulheres. Em seguida, se destaca a faixa etária de 22 a 24 anos, porém, neste caso há um predomínio de homens, conforme ilustra a Figura 3. 
Figura 3 - Faixa etária de acordo com o sexo dos respondentes

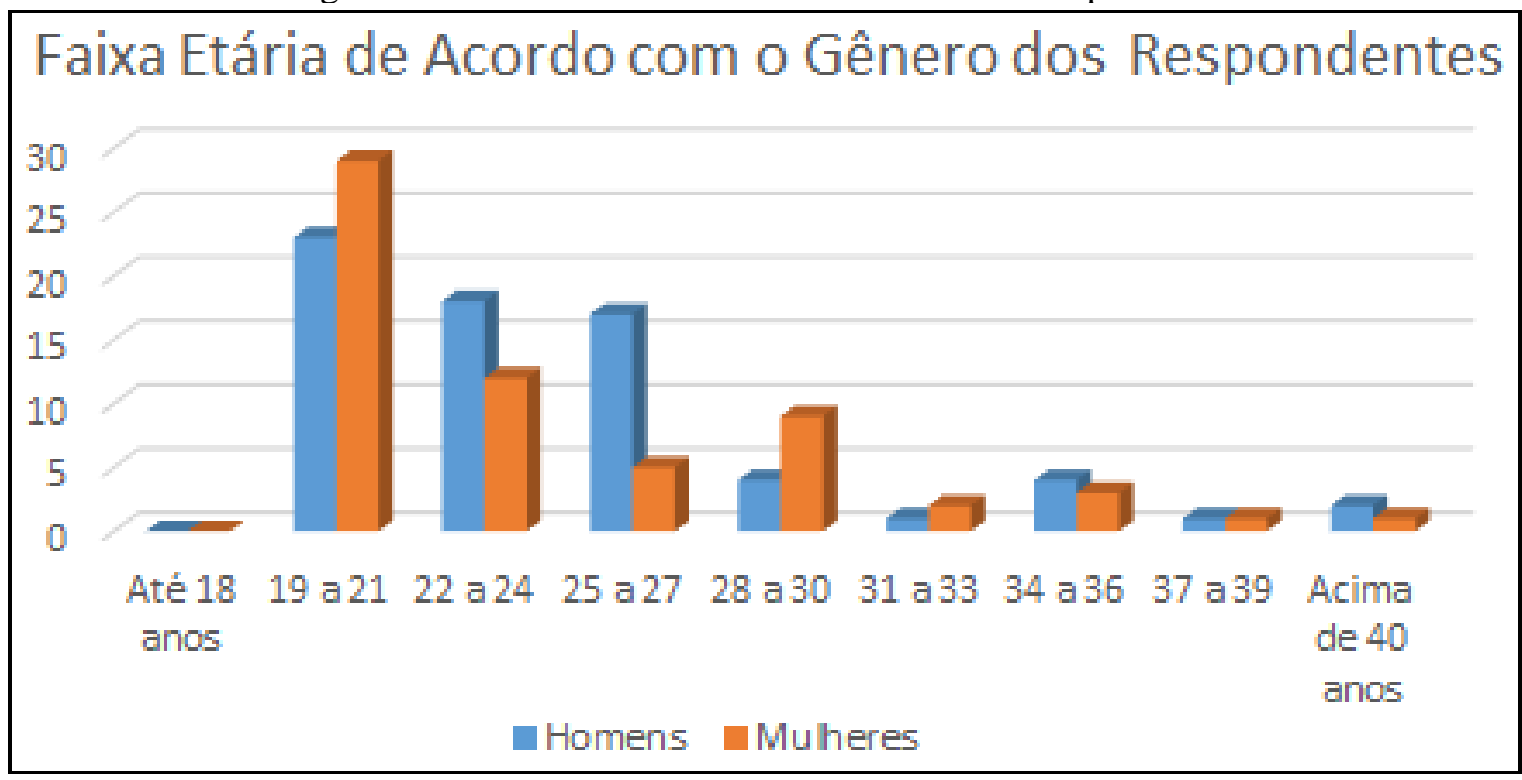

Fonte: Dados da Pesquisa, 2019.

Já no que tange à renda familiar mensal dos respondentes, percebeu-se um predomínio na faixa de renda que se estende de $\$ 2001,00$ a $\$ 3000,00$ reais, seguida pelas faixas de renda que se estende de $\$ 1001,00$ a $\$ 2000,00$ reais, e da faixa de $\$ 3001,00$ a $\$ 4000,00$ reais, conforme demonstra o Quadro 2.

Quadro 2 - Renda familiar mensal dos respondentes

\begin{tabular}{|c|c|}
\hline Renda familiar mensal & Frequência \\
\hline Até $\$ 1000,00$ & $5,4 \%$ \\
\hline De $\$ 1001,00$ a $\$ 2000,00$ & $21,4 \%$ \\
\hline De $\$ 2001,00$ a $\$ 3000,00$ & $37,6 \%$ \\
\hline De $\$ 3001,00$ a $\$ 4000,00$ & $18 \%$ \\
\hline De $\$ 4001,00$ a $\$ 5000,00$ & $10,1 \%$ \\
\hline De $\$ 5001,00$ a $\$ 6000,00$ & $6,3 \%$ \\
\hline Acima de $\$ 6000,00$ & $1,2 \%$ \\
\hline
\end{tabular}

Fonte: Dados da Pesquisa, 2019.

Ao se investigar o município de residêcia dos respondentes, constatou-se que há uma ampla diversificação, pois ao todo foram contemplados respondentes de 23 municípios, sendo que a grande maioria, ou seja, 72 respondentes, residem no município de Campo Mourão, o que corresponde a 55\% da amostra investigada, conforme se observa na Figura 4. 
Figura 4 - Município de residência dos respondentes

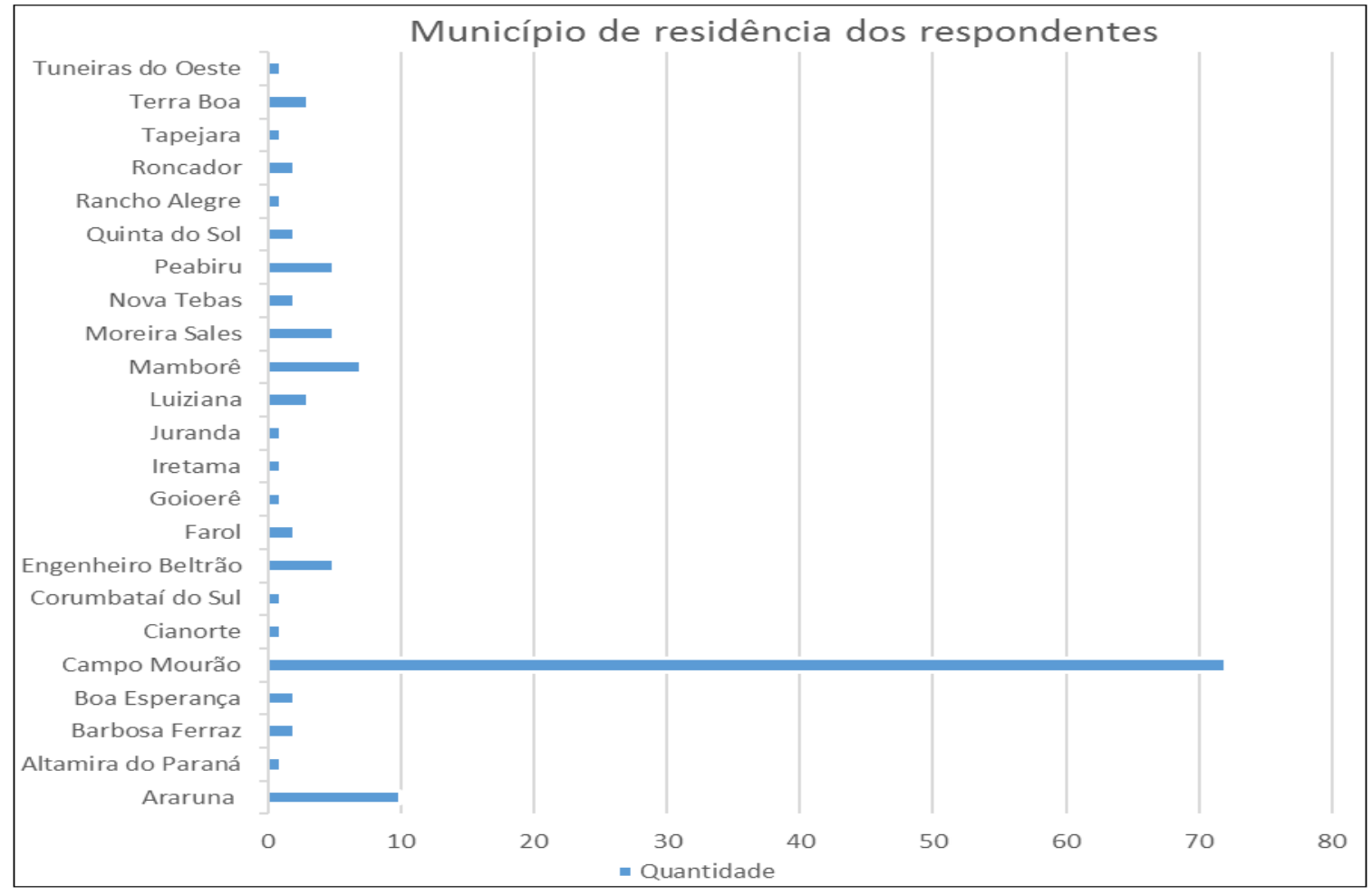

Fonte: Dados da Pesquisa, 2019

Quando se questionou quantos aparelhos celulares ativos os respondentes possuíam atualmente, 81,82\% dos respondentes afirmou que possui 1 aparelho ativo, enquanto que, $12,12 \%$ dos respondentes afirmou ter 2 aparelhos celulares ativos, ao passo que 5,31\% dos respondentes disse que possui 3 aparelhos celulares, e apenas $0,75 \%$ afirmou que possui mais de 3 celulares ativos, conforme demostra a Figura 5. Salienta-se que não houve respondentes que não possuem aparelhos celulares ativos.

Figura 5 - Levantamento da quantidade de aparelho celular que cada respondente possui

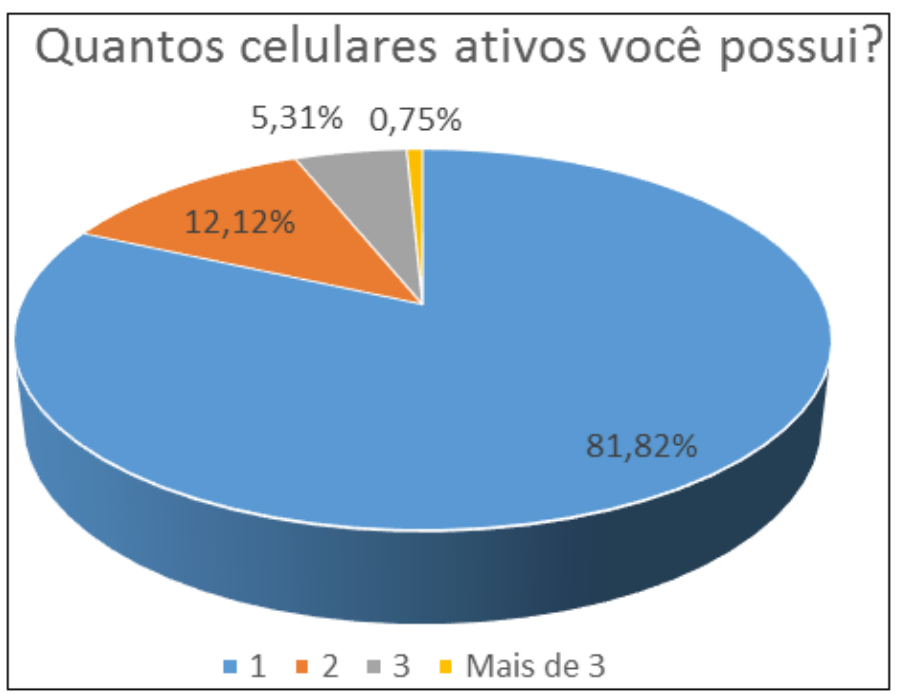

Fonte: Dados da Pesquisa, 2019. 
Quando se questionou há quanto tempo os respondentes haviam trocado de celular, observou-se que a grande maioria, ou seja, 50,75\% dos respondentes, trocou de aparelho no último ano, enquanto que 37,13\% dos respondentes, trocou há dois anos e apenas $12,12 \%$ dos respondentes fez a troca de aparelho há três anos ou mais, conforme demonstra a Figura 6. Não houve respondentes que nunca trocou de aparelho celular.

Figura 6 - Informações sobre o tempo relacionado a troca de aparelhos celulares realizada pelos respondentes

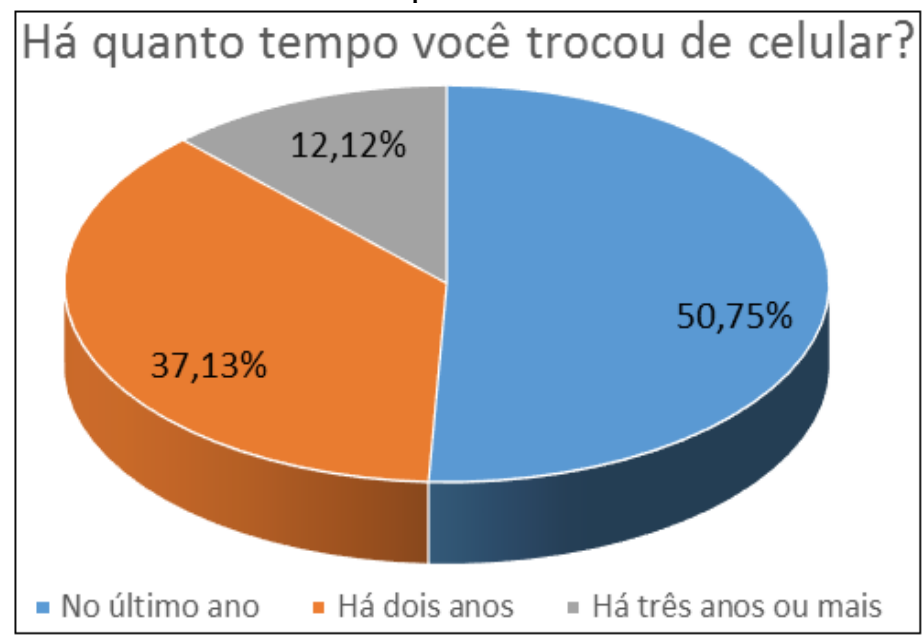

Fonte: Dados da Pesquisa, 2019.

Ao se investigar a incidência de substituição de aparelhos celulares, mesmo que estes ainda estejam em boas condições de uso, percebeu-se que 53,78\% dos respondentes afirmou ter realizado a substituição nestas circunstâncias, ao passo que 46,22\% da amostra afirmou que não costuma realizar a substituição do aparelho nestes casos, como demonstra a Figura 7.

Figura 7 - percentual de respondentes que já substituíram um bom aparelho em boas condições de uso, e percentual de respondentes que nunca substituíram um celular em boas condições de uso

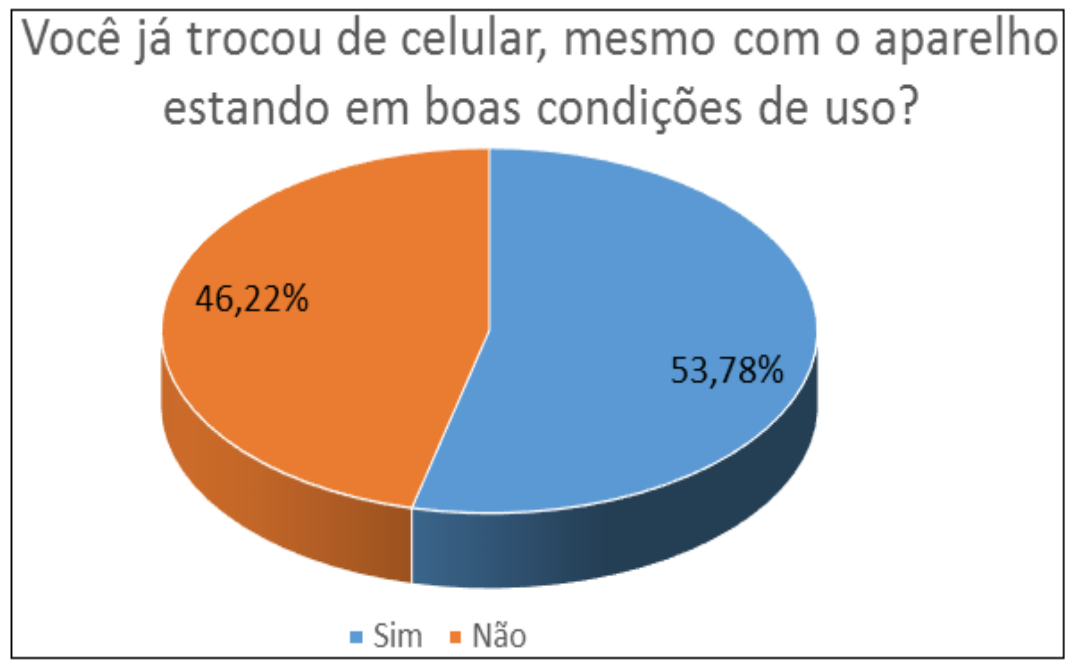

Fonte: Dados da Pesquisa, 2019. 
Procusou-se levantar qual o motivo que leva os respondentes a fazer a substituição do celular. As respostas obtidas demonstram que 37,13\% somente faz a substituição quando o aparelho apresenta algum defeito, seguido daqueles que somente fazem a substituição por necessidade, correspondendo a 30,30\%, e daqueles que somente fazem a substituição quando o aparelho não apresenta mais condições de uso, correspondendo a 14,40\% da amostra investigada, conforme a Figura 8.

Figura 8 - Motivo que levou os respondentes a realizar a troca do aparelho celular

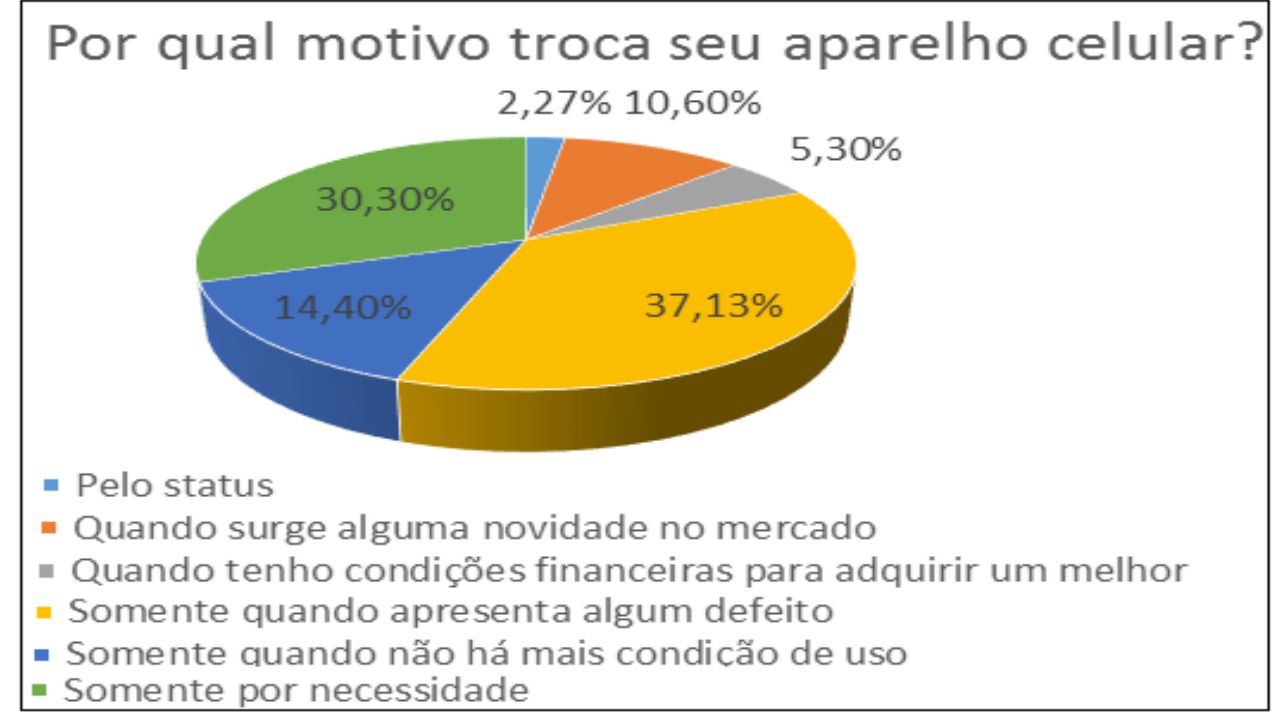

Fonte: Dados da Pesquisa, 2019.

Observou-se ainda que $44,70 \%$ dos respondentes não trocariam de celular com maior frequência, mesmo que o dinheiro não se configurasse como um fator limitador de consumo. Todavia, conforme demonstra a Figura 9, há uma predominância maior de respondentes que afirmaram que se o dinheiro não se constituísse como um fator limitante, certamente trocariam de aparelho com maior frequência.

Figura 9 - Comportamento de consumo dos respondentes em relação a disponibilidade de recursos financeiros e a constância na substituição de celulares

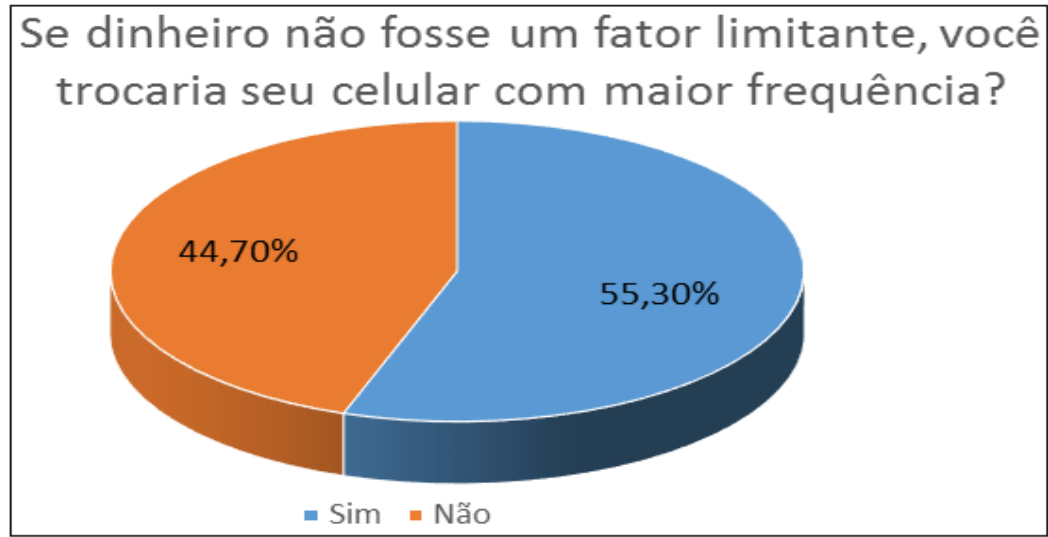

Fonte: Dados da Pesquisa, 2019. 
Ao investigar quantos respondentes possuíam algum aparelho celular parado em sua casa, que está com algum defeito ou que simplesmente não utiliza, constatou-se que a grande maioria não possui, mas o índice referente aos respondentes que possuem no mínimo um celular parado em sua residência, equivale a 31,06\%, constituindo um índice bastante elevado, conforme demonstra a Figura 10.

Figura 10 - No momento, você possui algum celular com defeito ou que não utiliza?

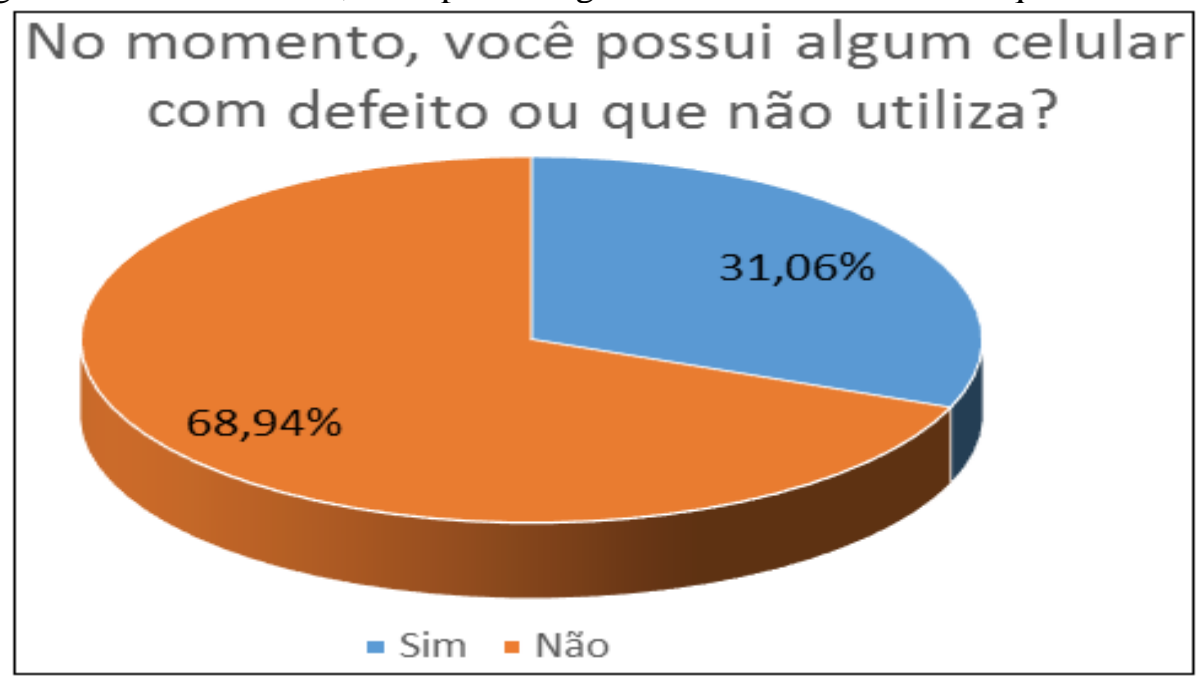

Fonte: Dados da Pesquisa, 2019.

Quando questionados sobre qual destino é dado para o celular antigo quando compra um novo, a maioria dos respondentes, isto é, $31,06 \%$, afirmou que mantém o aparelho antigo. Enquanto que 27,27\% dos respondentes afirmou que costuma vender o aparelho antigo, o que contribui no custeio do aparelho adquirido. Destaca-se ainda que 19,70\% dos respondentes afirmou que descarta o aparelho antigo num local de descarte adequado. Contudo, 13,64\% afirmou que faz o descarte no lixo comum, o que se configura como um descarte inadequado, conforme demostra a Figura 11.

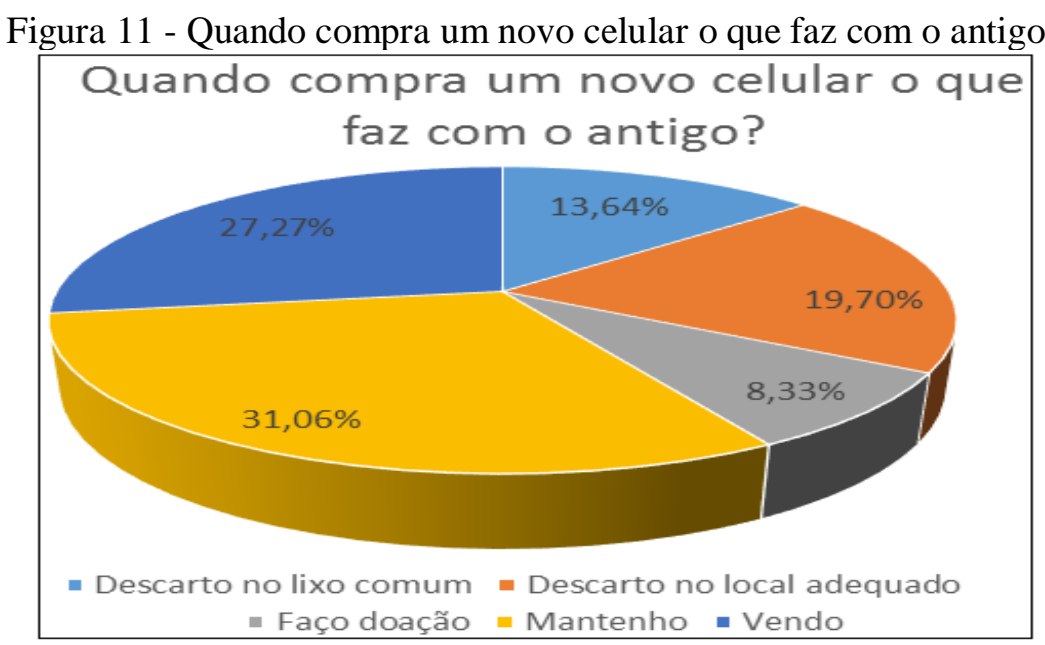

Fonte: Dados da Pesquisa, 2019. 
Buscando identificar o nível de conhecimento dos respondentes em relação aos canais de retorno dos aparelhos celulares e de suas baterias no pós-consumo, questionou-se os mesmos sabiam o que é logística reversa. As respostas obtidas denotam que 77,27\% dos respondentes afirmou saber o que é logística reversa, conforme a Figura 12.

Figura 12 - Você sabe o que é logística reversa?

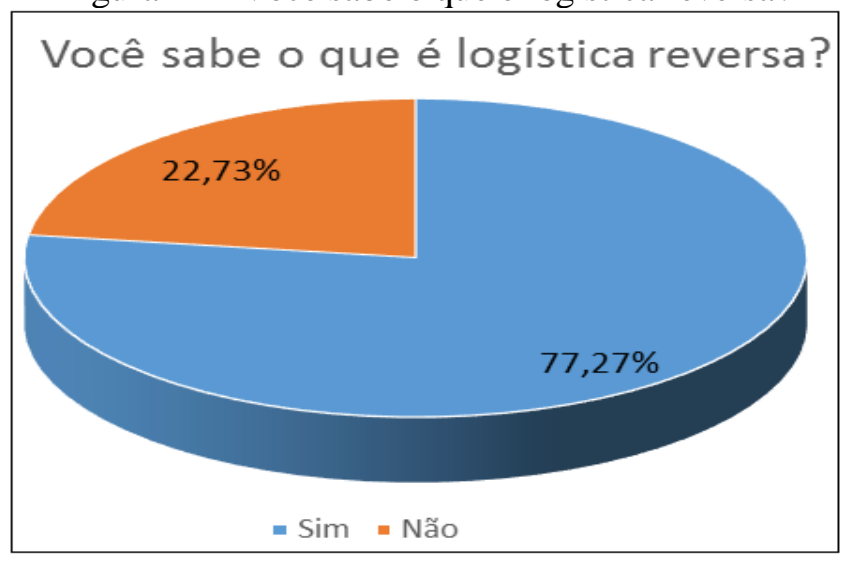

Fonte: Dados da Pesquisa, 2019.

Ao indagar a opinião dos respondentes em relação a maneira mais prática de descarte de celulares, percebeu-se que 30\% deles respondeu que a maneira mais prática consiste em entregar os aparelhos em ecopontos, em seguida estão $28,58 \%$ dos respondentes que afirmou que a revenda de celulares para outras pessoas consiste na maneira mais prática de descarte, e $24,29 \%$ disse que a entrega do aparelho antigo para obter desconto na hora de comprar um novo celular representa a forma mais prática de descarte. Dentro da opção "outro" houveram poucos respondentes, e os mesmos expressaram que haveria maior praticidade se houvesse a possibilidade de se fazer o descarte de celulares com defeitos ou obsoletos em empresas que prestam assistências técnicas, conforme ilustra a Figura 13.

Figura 13 - Opinião dos respondentes em relação a maneira mais prática de se fazer o descarte de celulares

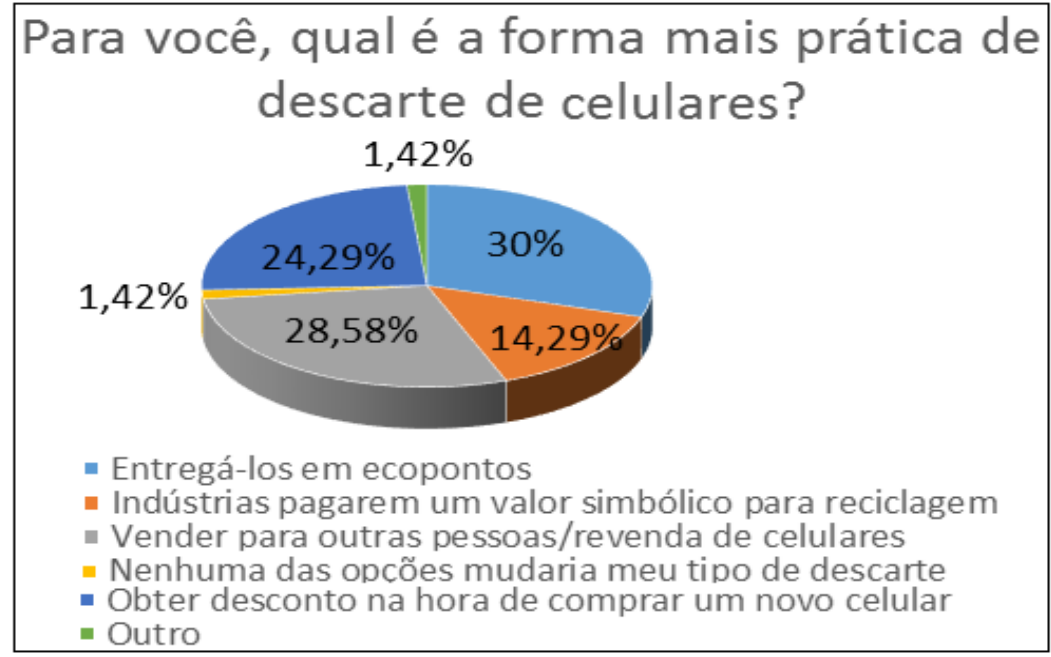

Fonte: Dados da Pesquisa, 2019. 
Ao se investigar a opinião dos respondentes em relação a responsabilidade de dar a destinação correta dos celulares, pôde-se observar que a grande maioria, ou seja, 27,28\% acreditam que a responsabilidade é dos consumidores, ao passo que $25 \%$ acham que a responsabilidade é dividida entre consumidores e fabricantes. Em seguida estão os 23,50\% que acreditam que a responsabilidade é apenas dos fabricantes, e os 8,34\% que entendem que esta responsabilidade é conjunta entre consumidores, fabricantes, operadoras e o governo, conforme nos mostra o Quadro 3.

Quadro 3 - Opinião dos respondentes em relação a responsabilidade de dar a destinação correta dos celulares

\begin{tabular}{|c|c|}
\hline A responsabilidade de dar a destinação correta dos celulares é: & $\mathbf{( \% )}$ \\
\hline Das Operadoras & $0,75 \%$ \\
\hline Dos consumidores & $27,28 \%$ \\
\hline Dos Fabricantes & $23,50 \%$ \\
\hline Do Governo & $0 \%$ \\
\hline Dos consumidores, Dos Fabricantes & $25 \%$ \\
\hline Dos consumidores, Dos Fabricantes, Das Operadoras, Do Governo & $3,79 \%$ \\
\hline Dos consumidores, Dos Fabricantes, Do Governo & $8,34 \%$ \\
\hline Dos Fabricantes, Das Operadoras & $0,75 \%$ \\
\hline Operadoras, Governo & $1,51 \%$ \\
\hline Dos Fabricantes, Das Operadoras, Do Governo & $0 \%$ \\
\hline Dos Fabricantes, Do Governo & $2,27 \%$ \\
\hline Dos consumidores, Das Operadoras & $5,30 \%$ \\
\hline
\end{tabular}

Fonte: Dados da Pesquisa, 2019.

A internet foi apontada pela maioria, isto é, 45,92\% dos respondentes, como sendo o meio de comunicação mais abrangente para obter informações sobre o descarte de celulares, seguida pelos pontos de vendas/trocas, que apresentou 20,75\% da opinião, e da TV que foi apontada por 17,04\% dos respodentes, conforme demonstra a Figura 14.

Figura 14 - Meios de comunicação considerados de melhor abrangência para obter informações sobre o descarte de celulares

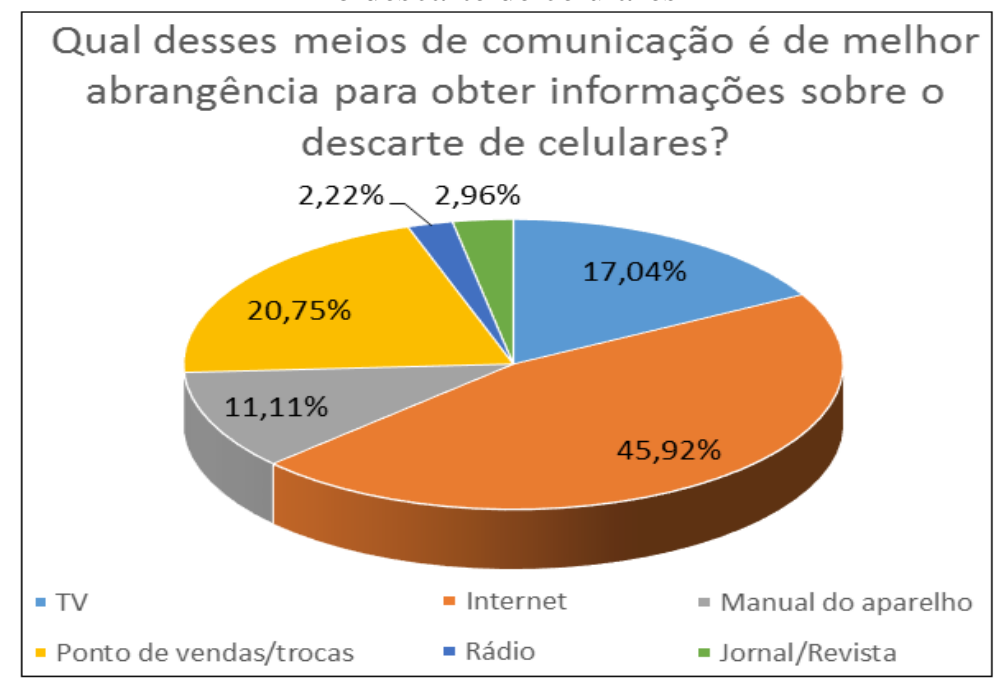

Fonte: Dados da Pesquisa, 2019. 
Diante do exposto, pôde-se constatar que o nível de conhecimento da maioria dos estudantes em relação ao descarte ecologicamente correto é satisfatório, porém, vários deles atestaram que possuem um ou mais aparelhos celulares em desuso guardados em suas residências, ou que já descartaram celulares no lixo comum. Demonstrando, portanto, a necessidade de ações por parte das empresas fabricantes e comercializadoras de tais produtos e do poder público no sentido de informar os riscos e os prejuízos que o descarte incorreto do lixo eletrônico pode acarretar e também indicar e disponibilizar os locais adequados para se fazer o descarte. Todavia, não se pode esquecer que se o consumidor não fizer a sua parte, e der a destinação correta dos resíduos eletrônicos, a logística reversa dos mesmos se torna ineficiente.

\section{CONSIDERAÇÕES FINAIS}

O público estudado nesta pesquisa se refere à população acadêmica que é composta em sua maioria por jovens. Salienta-se que em decorrência da facilidade de incorporar novas tecnologias esse público é considerado o perfil que geralmente tem um acesso maior a informação e que procura sempre estar atualizado. Ressalta-se ainda que, mesmo diante da falta de informações adequadas, de maneira geral, se constatou que os respondentes se sentem preocupados com o meio ambiente, conhecem os riscos causados pelo descarte incorreto dos celulares e de suas baterias, e muitos preferem guardar seus resíduos a descartá-los de maneira incorreta.

Destaca-se ainda que a falta de uma legislação mais rigorosa e que responsabilize aos fabricantes, aliada a ausência de uma rígida fiscalização, bem como a inexistência de estímulos fiscais para a prática da logística reversa, a falta de capacitação e tecnologia para reciclagem de componentes sofisticados e a ausência de uma educação ambiental mais abrangente, correspondem aos principais fatores que têm contribuído para o descarte indiscriminado dos resíduos eletrônicos. Nesse sentido, observa-se a necessidade de a iniciativa pública e privada desenvolver metas e estratégias para tratar a problemática dos aparelhos celulares enquanto um resíduo que carece de uma atenção maior sobre o seu processo de descarte.

\section{REFERÊNCIAS}

AÇÃO EDUCATIVA, ASSESSORIA PESQUISA E INFORMAÇÃO. A implementação dos Objetivos de Desenvolvimento Sustentável no Brasil e os desafios das metas em 
educação. Fevereiro de 2017. Disponível em:

http://www.acaoeducativa.org.br/desenvolvimento/wp-

content/uploads/2017/02/Implementa\%C3\%A7\%C3\%A3o-dos-ODS-Brasil2.pdf> Acesso em 23 de mai de 2020.

AFONSO, J. C. Lixo Eletroeletrônico. Ciência Hoje, São Paulo, v. 53, n. 314, 2014, p. 3640.

ANTIL, J. H. Socially Responsible Consumers: Profile and Implications for Public Policy. Journal of Macromarketing, v. 4, n. 2, pp. 18-39, 1984.

BRASIL. Lei Federal 12.305, de 02 de agosto de 2010. Institui a Política Nacional de Resíduos Sólidos. Diário Oficial [da] República Federativa do Brasil, Poder Executivo, Brasília, DF, 2010.

CARVALHO, C. M. B. de; XAVIER. L. H. Gestão de resíduos eletroeletrônicos: uma abordagem prática para a sustentabilidade. Rio de Janeiro: Elsevier, 2014.

CORTEZ, A. T. C.; ORTIGOZA, S. A. G. (Orgs). Consumo Sustentável: conflitos entre necessidade e desperdício. São Paulo: Unesp, 2007.

GIARETTA, J. B. Z.; TANIGUSHI, D. G.; SERGENT, M. T.; VASCONCELLOS, M. da P.; GÜNTHER, W. M. R. Hábitos relacionados ao descarte pós-consumo de aparelhos e baterias de telefones celulares em uma comunidade acadêmica. Saúde Soc. [online]. v.19, n.3, 2010, p.674-684.

GIL, A. C. Métodos e técnicas de pesquisa social. 6. Ed. São Paulo: Atlas, 2009.

HOPWOOD, Bill; MELLOR, Mary; O’BRIEN, Geoff. Sustainable Development: mapping diferrent approaches. Sustainable Development, v. 13, 2005, p. 38-52.

MACHADO, G. B. A matéria prima que vem dos resíduos de equipamentos eletroeletrônicos. Portal dos resíduos sólidos, 28 fev. 2015. Disponível em: < $<$ http://www.portalresiduossolidos.com/a-materia-prima-que-vem-dos-residuos-deequipamentos-eletro-eletronicos/>. Acesso em: 15 de jun de 2019.

MADURO-ABREU, A. Valores, consumo e sustentabilidade. Brasília. 2010. Tese (Doutorado em Desenvolvimento Sustentável) - Universidade de Brasília.

MOHR, L A.; WEBB, D. J.; HARRIS, K. E. Do Consumers Expect Companies to be Socially Responsible? The Impact of Corporate Social Responsibil-ity on Buying Behavior. The Journal of Consumer Affairs, v. 35, n. 1, pp. 45-72, 2001.

ORTIGOZA, S. A. G. De Consumo Dirigido a Consumo Sustentável: uma abordagem geográfica da questão. IX RCSP, 2003. Rio Claro, São Paulo. Disponível em: http://www.observatoriogeograficoamericalatina.org.mx/egal9/Geografiasocioeconomica/Geo grafiaespacial/13.pdf.> Acesso em: 15 de jun de 2019. 
PUJADAS, C. H.; FIGUEROA, M. F.; GARCÍA, M. L.; HERNÁNDEZ, J.J. Consumo Sostenible ante la Crisis Global. Revista de Ciencia Política, Buenos Aires, n. 8, 2009. Disponível em: http://www.revcienciapolitica.com.ar/num8art5.php> Acesso em 17 de jul de 2019.

RELATÓRIO DA ONU - NAÇÕES UNIDAS NO BRASIL. Brasil produziu 1,4 milhão de toneladas de resíduos eletrônicos em 2014, afirma novo relatório da ONU. Nações Unidas no Brasil. 20 de maio de 2015. Disponível em: https://nacoesunidas.org/brasil-produziu-14milhao-de-toneladas-de-residuos-eletronicos-em-2014-afirma-novo-relatorio-da-onu/> acesso em 05 de jul de 2019.

REVLOG - European Working Group on Reverse Logistics. 2009. Disponível em: http://www.fbk.eur.nl/OZ/REVLOG/ Acesso em: 08 de jul de 2019.

SHIBAO, F. Y.; MOORI, R. G.; SANTOS, M. R. A logística reversa e a sustentabilidade empresarial. VIII Seminário em Administração. Anais... São Paulo: FEA-USP, 2010. Disponível em: < http://web-resol.org/textos/a_logistica_reversa_e_a_sustentabilidade_ empresarial.pdf $>$. Acesso em: 14 de jun de 2019.

SILVA, M. E. da. Consumo sustentável: a articulação de um constructo sob a perspectiva do desenvolvimento sustentável. Revista Eletrônica de Ciência Administrativa - RECADM. Porto Alegre, 2012.

SODRÉ, M. G. Padrões de consumo e meio ambiente. In: Comércio e meio ambiente Direito, economia e política. São Paulo: SMA, 1996.

30ª Pesquisa Anual de Administração e Uso de Tecnologia da Informação nas Empresas, realizada pela Fundação Getúlio Vargas de São Paulo (FGV-SP), 2018. Disponível em: https://epocanegocios.globo.com/Tecnologia/noticia/2019/04/brasil-tem-230-milhoes-desmartphones-em-uso.html> Acesso em 03 de jul de 2019. 